Figure S1 (Wontakal et. al.)

A.

1)

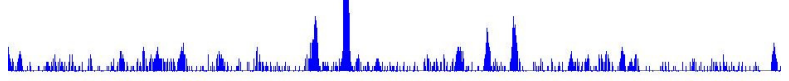

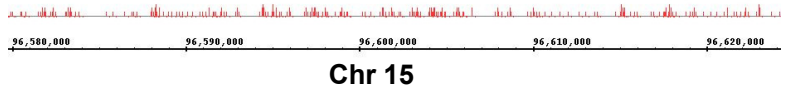

3)
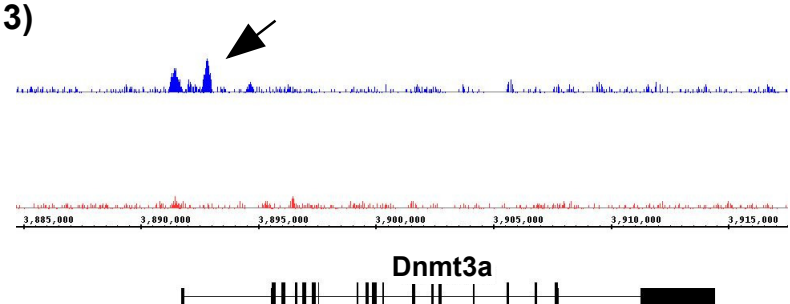

B.

1)

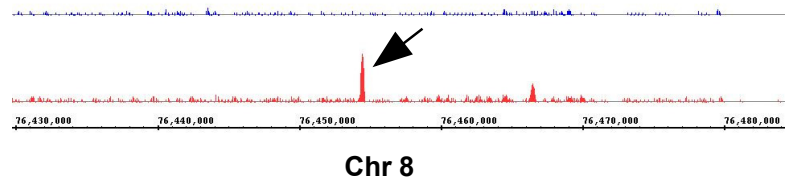

3)

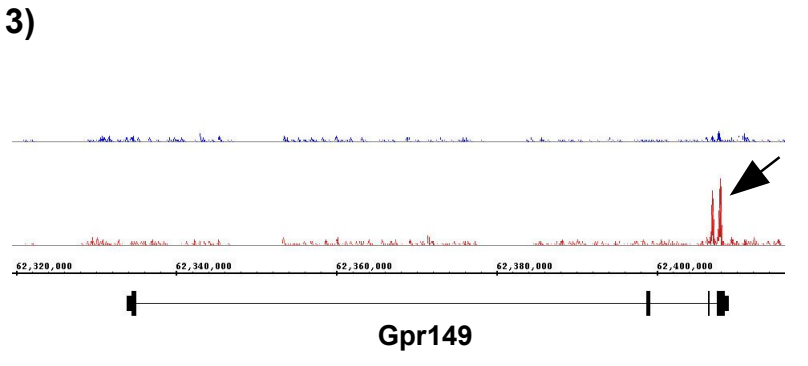

)
2)

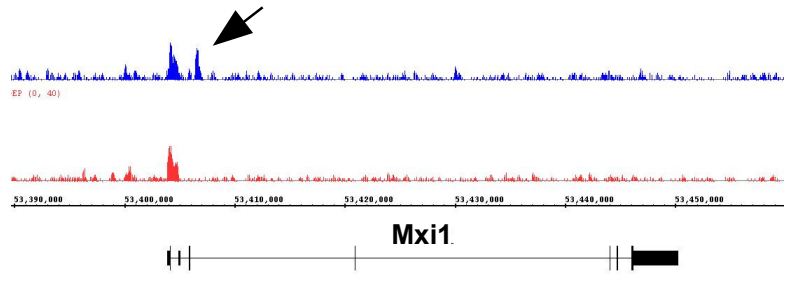

4)

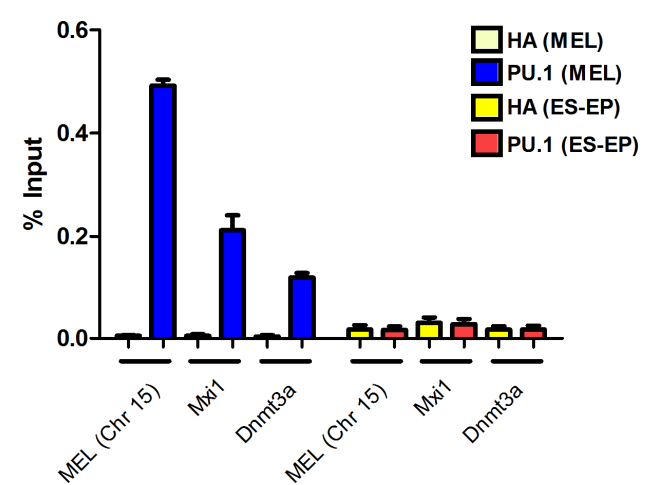

\title{
ES-EP Enriched
}

2)

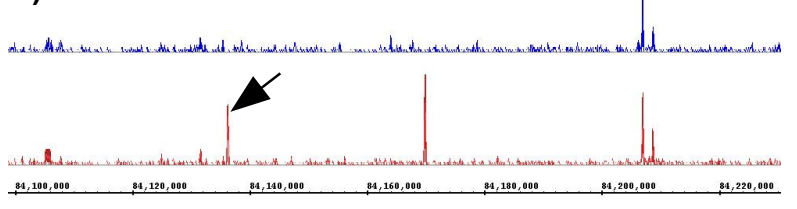

Mta3

4)

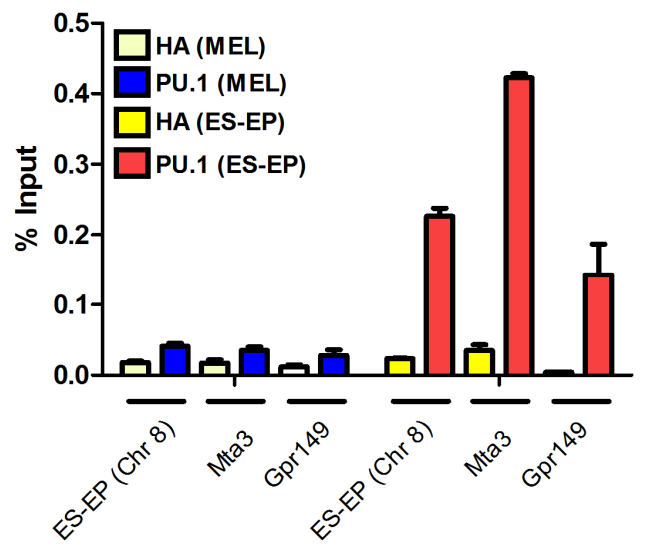

